Supplementary materials:

Table S1. Effect of simulated GI digestion on ACEi activity of T-EWH

\begin{tabular}{lccc}
\hline Activity & T-EWH & Pepsin & Pancreatin \\
\hline $\mathrm{IC}_{50}(\mathrm{mg} / \mathrm{mL})$ & $1.0^{\mathrm{a}}$ & $0.2^{\mathrm{c}}$ & $0.5^{\mathrm{b}}$
\end{tabular}

Values do not share a common superscript letter differ $(P<0.05)$.

Table S2. Molecular weight and sources of fractions of identified peptides from T-EWH

\begin{tabular}{|c|c|c|c|}
\hline Peptide & Molecular weight & Parent protein & Fraction \\
\hline \multicolumn{4}{|c|}{ Tri-peptides } \\
\hline EKR & 431.1952 & Ovotransferrin & F3-4-5 \\
\hline EQR & 431.1952 & Ovoinhibitor & F3-4-5 \\
\hline KLP & 356.2380 & Ovalbumin & F3-4-5 \\
\hline NLR & 401.2505 & Ovotransferrin & F3-5-6 \\
\hline PRI & 384.2859 & Ovoinhibitor & F3-4-4 \\
\hline PYK & 406.1976 & Ovotransferrin & F3-5-5 \\
\hline \multicolumn{4}{|c|}{ Tetra-peptides } \\
\hline AERF & 521.2424 & Clusterin & F3-4-5 \\
\hline APYK & 477.2363 & Ovotransferrin & F3-5-5 \\
\hline INKV & 472.3228 & Ovalbumin & F3-4-3/-4 \\
\hline VIRW & 572.3111 & Ovotransferrin & F4-11-3 \\
\hline \multicolumn{4}{|c|}{ Penta-peptides } \\
\hline LAPYK & 590.3355 & Ovotransferrin & F3-5-5 \\
\hline LKISQ & 587.3538 & Ovalbumin & F4-5-3 \\
\hline LKYAT & 594.3229 & Ovoglycoprotein & F4-5-3 \\
\hline PVLKD & 570.3619 & Ovotransferrin & F4-5-3, F4-4-5 \\
\hline SQAVH & 611.2360 & Ovalbumin & F3-4-5/-6 \\
\hline QAVHA & 524.2460 & Ovalbumin & F3-4-5 \\
\hline \multicolumn{4}{|c|}{ Hexa-peptides } \\
\hline ERQEKR & 844.4515 & Ovotransferrin & F4-4-5, F4-5-2/-3 \\
\hline INKVVR & 728.4545 & Ovalbumin & F3-4-6 \\
\hline KIMKGE & 704.3891 & Ovotransferrin & F4-11-4 \\
\hline LFLIKH & 769.485 & Ovalbumin-related protein $\mathrm{X}$ & F4-11-3 \\
\hline LGHWVY & 773.3147 & Ovoglycoprotein & F4-11-4 \\
\hline SSHEKY & 749.3455 & Ovotransferrin & F3-4-3 \\
\hline VQKATY & 708.3806 & Ovotransferrin & F3-4-3/-4/-5/-6 \\
\hline VYLPRM & 793.4156 & Ovalbumin & F4-11-3 \\
\hline \multicolumn{4}{|c|}{ Hepta-peptides } \\
\hline LTSVLMA & 733.4044 & Ovalbumin & F4-11-3 \\
\hline \multicolumn{4}{|c|}{ Ennea-peptides } \\
\hline FDKLPGFGD & 994.476 & Ovalbumin & F4-11-4 \\
\hline VNGSEKSKF & 995.4924 & Ovotransferrin & F3-5-6 \\
\hline
\end{tabular}



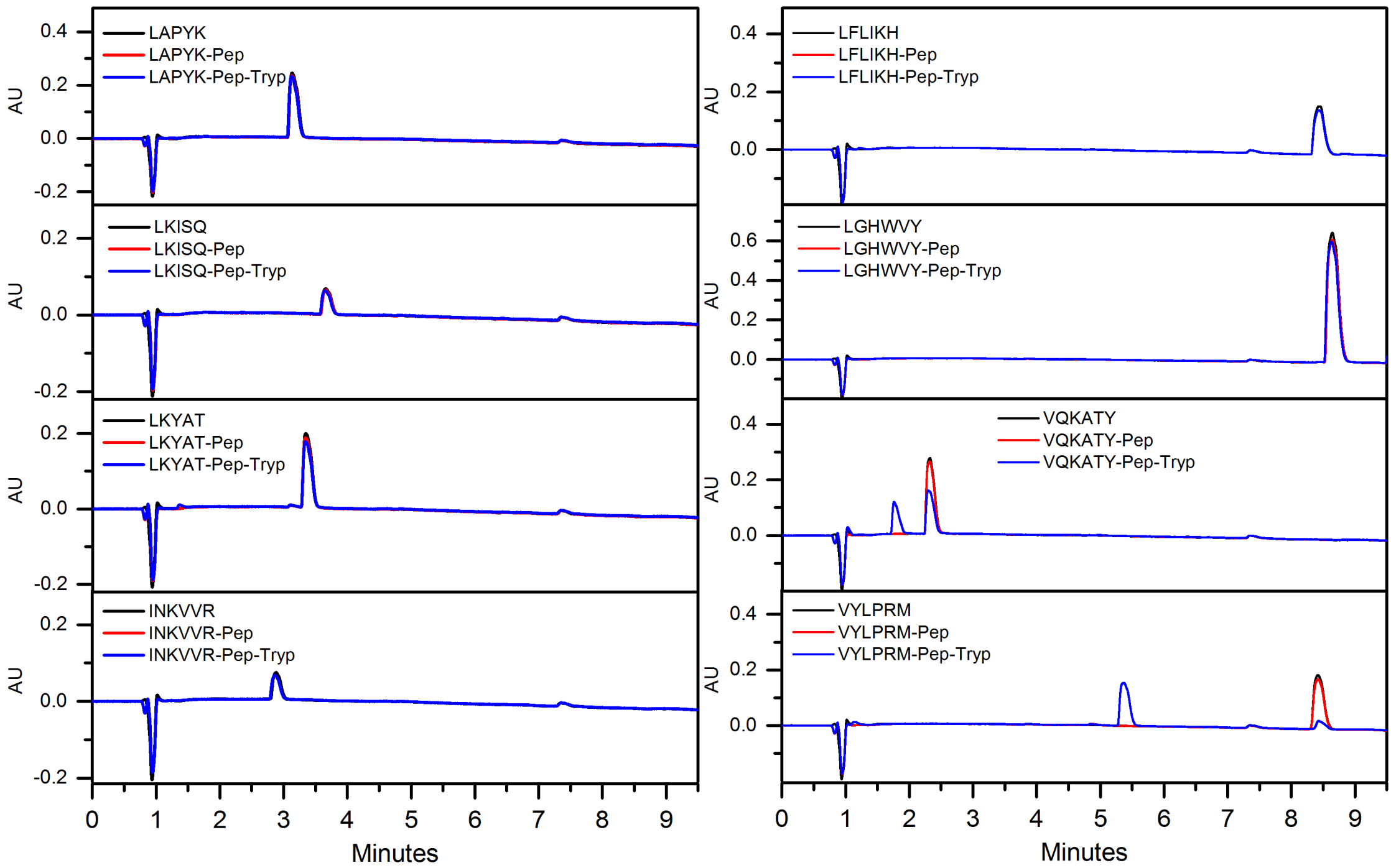

Figure $\mathrm{S} 1 \mathrm{Chromatograms}(10 \mu \mathrm{L})$ of peptides after digestion by pepsin (Pep, 1\% E/S, pH 2, $1.5 \mathrm{~h})$ and trypsin $($ Tryp, 1\% E/S, pH 7.5, $1.5 \mathrm{~h})$. Peptide concentration: $100 \mu \mathrm{g} / \mathrm{mL}$. HPLC Gradient of binary eluent system of water and acetonitrile: $1 \%-19.5 \%$ acetonitrile $(0-$ $9.5 \mathrm{~min})$. 


\section{Desalting procedures}

$\diamond$ Activate Sep-pak 35cc tC18 Cartridge (WAT043350, Waters, Milford, MA, USA) using 2 column volume (CV) of 50\% ACN (acetonitrile), and then store in 50\% ACN for $2 \mathrm{~h}$.

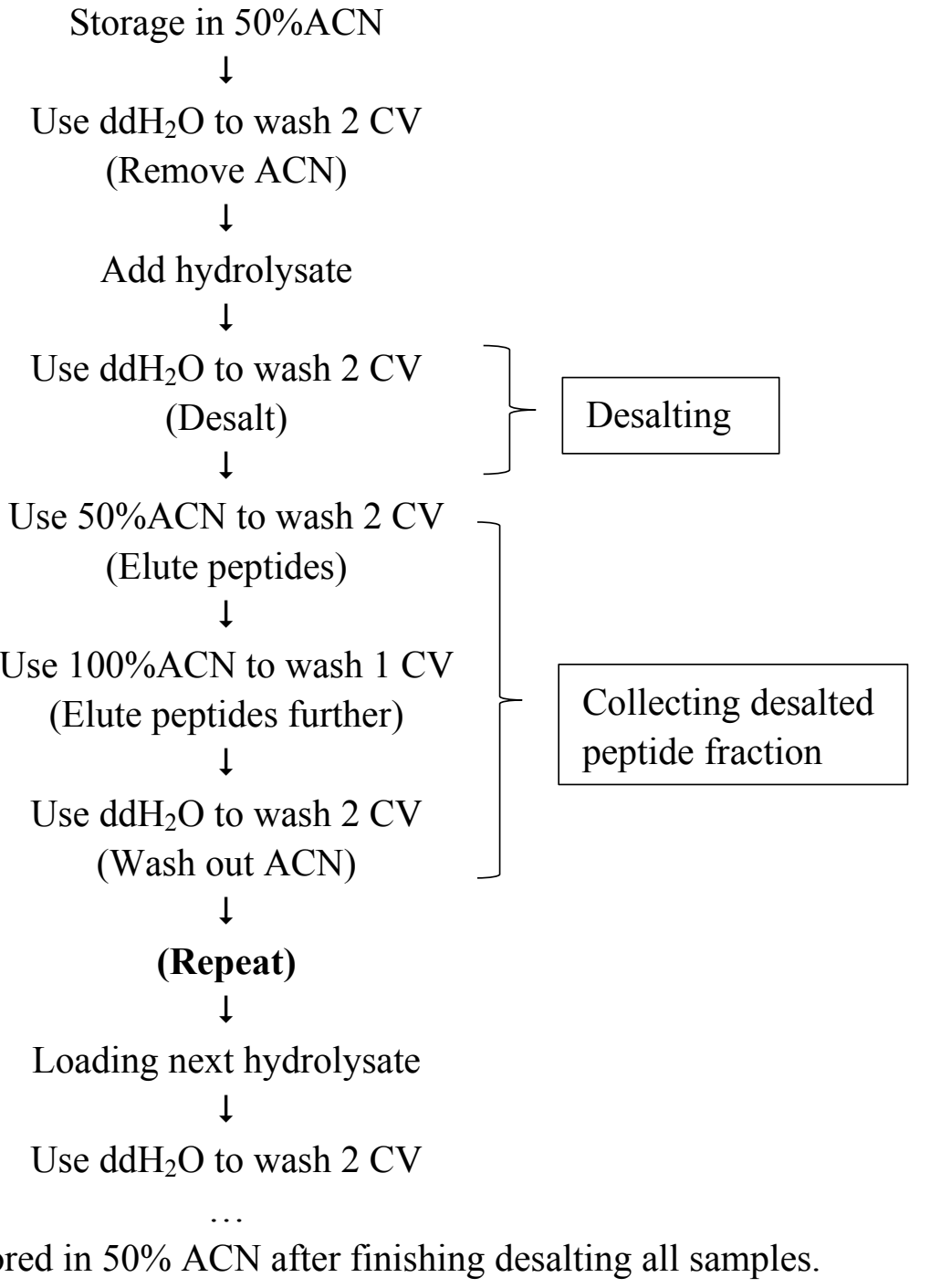

